\title{
ASSESSING THE VIRULENCE OF OPHIOSTOMATOID FUNGI ASSOCIATED WITH THE PINE-INFESTING WEEVILS TO SCOTS PINE Pinus sylvestris L. SEEDLINGS
}

\author{
Robert Jankowiak
}

\author{
Agricultural University of Cracow, Department of Forest Pathology \\ Al. 29 Listopada 46, 31-425 Cracow, Poland \\ Poland. e-mail: rljankow@cyf-kr.edu.pl
}

Received: 19.11.2012

\begin{abstract}
The pine-infesting weevils are known to be effective vectors of ophiostomatoid fungi. To understand more about fungal virulence of these fungi, inoculation studies were conducted on Scots pine (Pinus sylvestris L.). Two-year-old seedlings were wound-inoculated with one of eleven ophiostomatoid fungi associated with pine-infesting weevils. After 11 weeks, a darkened lesion, extending from the point of inoculation, was observed in all species, except for Ophiostoma cf. abietinum Marm. \& Butin, Ophiostoma quercus (Georgev.) Nannf., and Sporothrix inflata de Hoog. Seedling mortality was observed in seedlings inoculated with Leptographium truncatum (M.J. Wingf. \& Marasas) M.J. Wingf., Leptographium lundbergii Lagerb. \& Melin, Leptographium procerum (W.B. Kendr.) M.J. Wingf., Grosmannia radiaticola (J.J. Kim, Seifert \& G.H. Kim) Zipfel, Z.W. de Beer \& M.J. Wingf., Ophiostoma floccosum Math.-Käärik, Ophiostoma minus (Hedgc.) Syd. \& P. Syd., and Ophiostoma piliferum (Fr.) Syd. \& P. Syd. Ophiostoma minus and L. truncatum caused the largest lesions and sapwood blue-stain in Scots pine. Grosmannia radiaticola, Ophiostoma piceae (Münch) Syd. \& P. Syd., O. floccosum, O. piliferum, L. lundbergii, and L. procerum produced significantly smaller lesions and sapwood blue-stain than $O$. minus and L. truncatum, while $O$. cf. abietinum, $O$. quercus and $S$. inflata did not cause any lesions.
\end{abstract}

Key words: blue-stain fungi, bark weevils, pathogenicity, Pinus sylvestris, regeneration weevils

\section{INTRODUCTION}

The pine-infesting weevils, including Hylobius abietis (L.), Pissodes castaneus (De Geer), Pissodes piniphilus (Herbst) and Pissodes pini (L.), are considered to be an important forest pest on Scots pine ( $P i$ nus sylvestris L.) in Poland (Kolk and $\mathrm{Starzyk}$,
1996). These weevils occupy a variety of ecological niches. Pissodes castaneus is known to have a significant economic impact on regenerating stands and prefers the root neck of young (4-15-year-old) pine trees. Pissodes piniphilus and $P$. pini infest the aboveground parts of older trees; the former of these is mainly found on 30-40-year-old pine trees, while the latter colonises older trees ( $\mathrm{D}$ a y et al. 2004). Of the four species mentioned, $H$. abietis seemed to be the most important pest in forest, because adults prefer to feed on bark of young seedlings causing growth reduction or plant death (W a ll e r t z et al. 2005).

Ophiostomatoid fungi are known to be associated with many weevils in North America (W in g field, 1983; Nevill and A lex ander, 1992; J a cobs and Wingfield, 2001; Eckhardt et al. 2007; $\mathrm{Z}$ a n z ot et al. 2010), however the interactions between ophiostomatoid fungi and weevils have been poorly studied in Europe (P i o u, 1993; L é v i e u x et al. 1994). In France, H. abietis has been found carrying Leptographium procerum (W.B. Kendr.) M.J. Wingf., Leptographium wingfieldii M. Morelet, Ophiostoma canum (Münch) Syd. \& P. Syd. and Ophiostoma piliferum (Fr.) Syd. \& P. Syd. (Piou, 1993), while Ophiostoma minus (Hedgc.) Syd. \& P. Syd., Ophiostoma piceae (Münch) Syd.\& P. Syd., Ophiostoma pluriannulatum (Hedgc.) Syd. \& P. Syd., Ophiostoma stenoceras (Robak) Nannf. and Ceratocystiopsis minuta (Siemaszko) H.P. Upadhayay \& W.B. Kendr. were occasionally found in association with $P$. pini (M a th i e n s e n- Kä äri k, 1953, 1960). In contrast to their previous studies, Jankowiak and Bilański (2013a) recently showed that considerably more diverse fungal species were associated with $H$. abietis. In Poland, 
H. abietis has been found to be infested mainly with Leptographium lundbergii Lagerb. \& Melin, L. procerum, Ophiostoma quercus (Georgev.) Nannf., Ophiostoma floccosum Math.-Käärik, O. piliferum, Sporothrix inflata de Hoog, and ten other ophiostomatoid species. In this study, $H$. abietis also acted as an effective vector carrying ophiostomatoid species to $P$. sylvestris seedlings, especially in the case of $L$. procerum and $S$. inflata. In a recent study in Poland, $P$. castaneus has been found carrying mainly $L$. procerum and $S$. inflata, while Ophiostoma cf. rectangulosporium Ohtaka, Masuya \& Yamaoka, O. minus and $O$. quercus have often been found in association with $P$. piniphilus and $P$. pini (J a n k ow i a k and B il ań ski, 2013b). The data of Jankowiak and Bilański (2013ab) showed that the community of ophiostomatoid fungi associated with pine-infesting weevils was generally similar to the spectrum of fungi reported from different species of bark beetles in Europe ( $\mathrm{K}$ i r i s i t s, 2004; L i n n a k o s ki et al. 2012). The pathogenicity of these fungal associates has been studied in artificial inoculation trials using mature trees and seedlings ( $\mathrm{K}$ i r i s it s , 2004). The majority of the ophiostomatoid species reported in these studies are capable of destroying plant cells and even some of them, e.g. O. minus or L. wingfieldii, demonstrated a high level of virulence to Scots pine (L å n g s t r ö m et al. 1993; S o 1 h e i m et al. 1993; Li e u ti e r et al. 2004). However, only the pathogenicity of the most common fungal associates has been studied in artificial inoculation trials. Moreover, these inoculation experiments have also been carried out on various Pinus species. Little is, however, known regarding the potential pathogenicity other ophiostomatoid fungi, especially those associated with weevils occurring on Scots pine. This is especially important, because $H$. abietis adults introduced spores of ophiostmatoid fungi to pine seedling during maturation feeding (J a n k ow i a k and B i la ń sk i , 2013a). Certainly, the presence of virulent fungal species in seedlings damaged by $H$. abietis feeding may affect plant health. Knowledge about virulence of ophiostomatoid fungi is also very important because several ophiostomatoid fungi of the Leptographium species, including Leptographium terebrantis S.J. Barras \& T.J. Perry, Leptographium serpens (Goid.) M.J. Wing., L. procerum and Grosmannia huntii (Rob-Jeffr.) Zipfel Z.W. de Beer \& M.J. Wingf. which have been isolated from the roots of diseased pines, and root-feeding insects vectors in the USA (Jacobs and Wingfield, 2001) have demonstrated a high level of virulence to pine ( $\mathrm{H}$ a r ring to n and Cobb, 1988).

The objective of the present study was to evaluate the pathogenicity of eleven ophiostomatoid species associated with pine-infesting weevils by inoculating 2-year-old Scots pine seedlings.

\section{MATERIALS AND METHODS}

To investigate the impact of the fungal associates of weevils on Scots pine, infection experiments were conducted on 2-year-old containerized Pinus sylvestris seedlings obtained from a nursery. Seedlings were grown in containers with a mixture of peat : perlite $(8.5: 1.5)$. The plants were maintained outdoor under ambient conditions and watered as required. Stem diameters at the inoculation site ranged from 3.1 to $6.8 \mathrm{~mm}$ (mean $4.48 \mathrm{~mm}$ ).

Eleven species of ophiostomatoid fungi associated with Hylobius abietis, Pissodes castanesus, Pissodes piniphilus, and Pissodes pini were used for inoculation (Table 1). Ophiostoma minus, a known pathogen of P. sylvestris, was used as a positive control to estimate fungal virulence in this experiment. All isolates used in this study were obtained during a survey of ophiostomatoid fungi associated with weevils attacking Scots pine in Poland and were identified based on morphology, DNA sequence comparison for two gene regions and phylogenetic analysis (Jankowiak and Bilański, 2013ab). One random isolates of each fungus was used. On the $4-5^{\text {th }}$ of April 2012, 330 seedlings were inoculated with selected isolates (30 seedlings for each isolate). Thirty plants were inoculated with sterile MEA as negative controls. Inoculations were made by cutting out a bark flap $(4 \times 8 \mathrm{~mm})$ with a sterile scalpel, placing inoculum on the exposed sapwood surface and covering it up with the bark flap and a Parafilm ${ }^{\circledR}$ M strip, as described by Krokene and Solheim (1998). The wounds were made on the first-year shoot of plants, four $\mathrm{cm}$ above the root collar. The inoculum consisted of a $3 \mathrm{~mm}$ disc of fungus growing on $2 \%$ MEA or sterile $2 \%$ MEA. The inoculum was taken from the margin of 12-day-old cultures grown at $22^{\circ} \mathrm{C}$.

Observations of plant mortality were performed at weekly intervals for 11 weeks. A seedling was considered dead when the stem and needles above the inoculation site were brown discoloured. After 11 weeks, all plants were harvested and the bark was removed around the inoculation site. The length of the necrotic lesion on the sapwood surface and the depth of any sapwood blue-stain were measured. Data on the depth of sapwood blue-stain and lesion length were subjected to ANOVA, using a general linear model (GLM) in Statistica statistical software (STATISTICA ${ }^{\circledR} 10.0$ (StatSoft, Inc., Tulsa, USA). Where significant treatment effects occurred $(\mathrm{p}<0.05)$, means were separated using Scheffe's test at $\mathrm{p}=0.05$. For fungal isolates, $2 \times 2$ tables and Chi-square test were used to determine differences in plant mortality.

Re-isolations of the inoculated fungi from each seedling were attempted by removing two small sapwood pieces $(1 \mathrm{x} 1 \mathrm{~mm})$ above and below the points of inoculation at a distance of $0.5-1 \mathrm{~cm}$ and placing them 
onto $2 \%$ MEA. In total, 720 plant pieces were used for re-isolations of fungi. Plates were incubated for
4 weeks at $22^{\circ} \mathrm{C}$ and then checked for the presence of the inoculated fungi.

Table 1

Fungal isolates used in the pathogenicity test

\begin{tabular}{lccc}
\hline \multicolumn{1}{c}{ Species } & Isolate numbers & Origin & Insect vector \\
\hline Grosmannia radiaticola & 535RJ & Koszęcin, beetle & H. abietis \\
Leptographium lundbergii & 1314RJP & Przedbórz, larvae & P. pini \\
Leptographium procerum & 630RJ & Jarosław, beetle & H. abietis \\
Leptographium truncatum & 599RJP & Pateraki, beetle & P. castaneus \\
Ophiostoma cf. abietinum & 764RJ & Czajkowa, beetle & H. abietis \\
Ophiostoma floccosum & 1545RJP & Jędrzejów, gallery & P. piniphilus \\
Ophiostoma minus & 1160RJp & Jędrzejów, gallery & P. piniphilus \\
Ophiostoma piceae & $601 \mathrm{RJ}$ & Jarosław, beetle & H. abietis \\
Ophiostoma piliferum & 1526RJP & Jędrzejów, larvae & P. pini \\
Ophiostoma quercus & 619bRJ & Jarosław, beetle & H. abietis \\
Sporothrix inflata & 297ARJP & Jędrzejów, gallery & P. castaneus \\
\hline
\end{tabular}

\section{RESULTS}

Mortality was observed throughout this experiment in the 2-year-old seedlings inoculated with Grosmannia radiaticola (J.J. Kim, Seifert \& G.H. Kim) Zipfel, Z.W. de Beer \& M.J. Wingf., Leptographium truncatum (M.J. Wingf. \& Marasas) M.J. Wingf., Leptographium lundbergii, Leptographium procerum, Ophiostoma floccosum, Ophiostoma minus, and Ophiostoma piliferum. The isolates of $L$. truncatum and $L$. lundbergii killed 23-33\% of the plants, while L. procerum, $G$. radiaticola, $O$. floccosum and $O$. minus caused the death of $10-17 \%$ of the seedlings. However, seedling survival was not significantly different between these fungal species. Ophiostoma piliferum contributed to the death of one seedling (Table 2). In the case of plants inoculated with these fungal isolates, the first mortality symptoms were observed 6-8 weeks after inoculation. Dying seedlings were characterized by the symptom of wilting of new shoots of the current year's growth and by yellow-brownish needles. No control plants or plants inoculated with isolates of Ophiostoma cf. abietinum Marm. \& Butin, Ophiostoma piceae, Ophiostoma quercus and Sporothrix inflata died (Table 2).

All fungal species, except $O$. cf. abietinum, $O$. quercus and $S$. inflata, caused dark-brown sunken lesions in pine seedlings. The lesions were generally covered with crystallized resin and extended vertically from the wounded area (Fig. 1 A-L). Ophiostoma minus and $L$. truncatum induced significantly larger necrotic lesions than the other fungi tested in comparison to the control seedlings. The lesions associated with $L$. lundbergii infection were also large and significantly different from the other species (Table 2). In seedlings inoculated with these species, the callus tissue was considerably damaged (Fig. 1 B, D, G). Four other ophiostomatoid species, including $G$. radiaticola, $L$. procerum, $O$. floccosum and $O$. piliferum, generated significantly smaller necrosis with a range of $8.30 \mathrm{~mm}$ to $8.72 \mathrm{~mm}$ (Table 2). In seedlings treated with these fungi, the wounds were partially healed (Fig. $1 \mathrm{~A}, \mathrm{C}, \mathrm{F}, \mathrm{I}$ ). Ophiostoma piceae caused necrosis of the smallest mean length $(5.47 \mathrm{~mm})$. Eleven weeks after inoculation, the callus tissue enclosed the wounds of all control plants and plants inoculated with $O$. cf. abietinum, $O$. quercus and $S$. inflata (Fig. $1 \mathrm{E}, \mathrm{J}, \mathrm{K}$ ).

All the fungi concerned, except $O$. cf. abietinum, O. quercus and $S$. inflata, caused sapwood blue-stain in the 2-year-old seedlings (Fig. 2 A-L). Similar to lesion length, $O$. minus and $L$. truncatum caused the largest sapwood blue-stain. Leptographium procerum also caused sapwood blue-stain of similar depth, however significantly smaller than $O$. minus (Table 2). Grosmannia radiaticola, $L$. lundbergii and $O$. piliferum generated the second largest zones of sapwood blue-stain ranging from $0.47 \mathrm{~mm}$ to $0.88 \mathrm{~mm}$ (Table 2). The depth of sapwood blue-stain was significantly smallest in pine seedlings treated with $O$. floccosum and $O$. piceae (Table 2).

Re-isolation of fungal species from inoculated seedlings confirmed infection. All fungal species were successfully re-isolated from the inoculated pines. Grosmannia radiaticola, $L$. procerum, $O$. floccosum, $O$. minus, $O$. piceae, $O$. quercus were successfully re-isolated from $100 \%$ of the plants, while L. lundbergii, L. truncatum, $O$. cf. abietinum, $O$. piliferum and S. inflata were re-isolated from $53-86 \%$ of the plants (Table 2). 

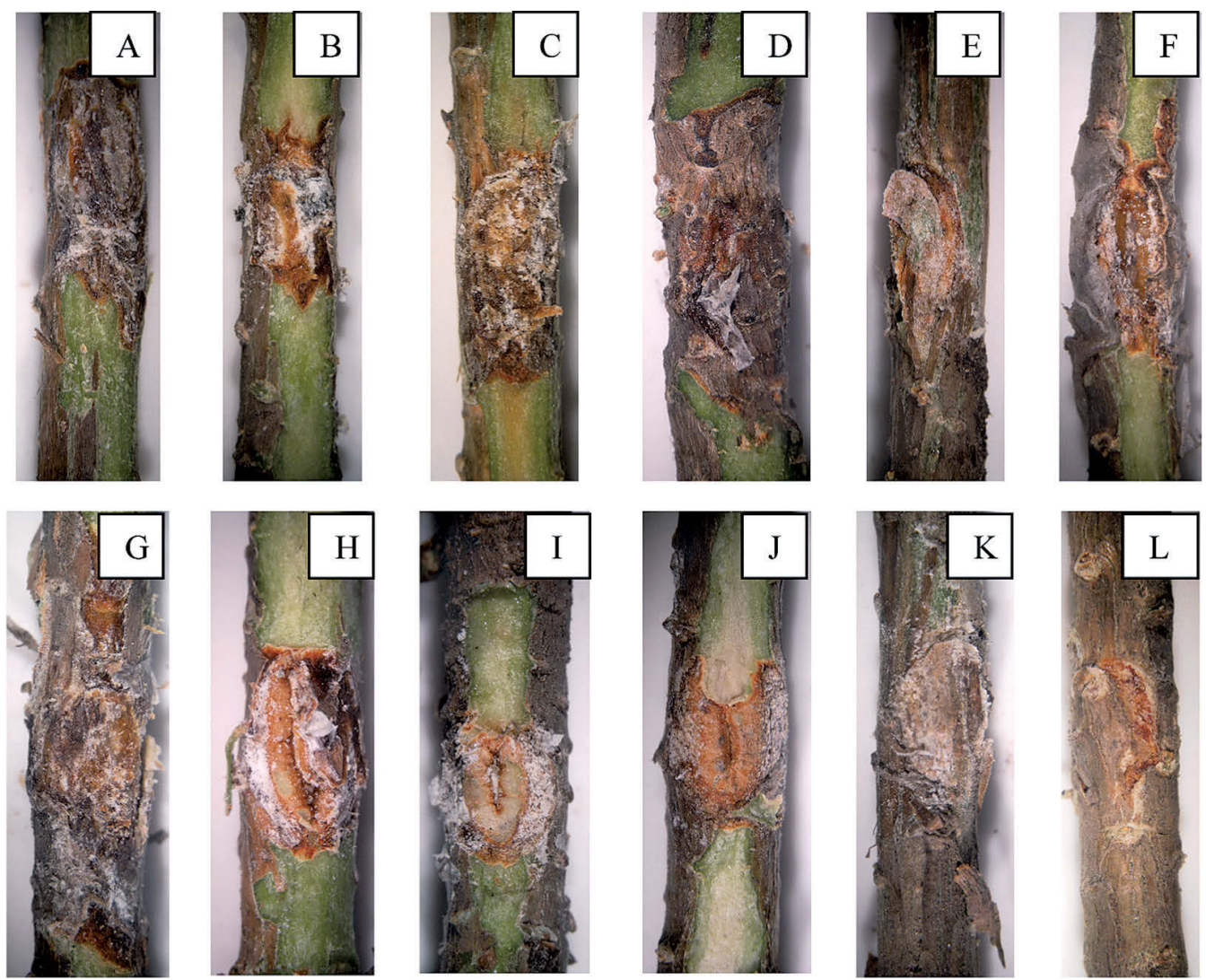

Fig. 1. Lesions on the surface of a pine stem caused by A - Grosmannia radiaticola, B - Leptographium lundbergii, C - Leptographium procerum, D - Leptographium truncatum, E - Ophiostoma cf. abietinum, F - Ophiostoma floccosum, $\mathrm{G}$-Ophiostoma minus, $\mathrm{H}$ - Ophiostoma piceae, I-Ophiostoma piliferum, J - Ophiostoma quercus, $\mathrm{K}$ - Sporothrix inflata, L - control (photo by R. Jankowiak).
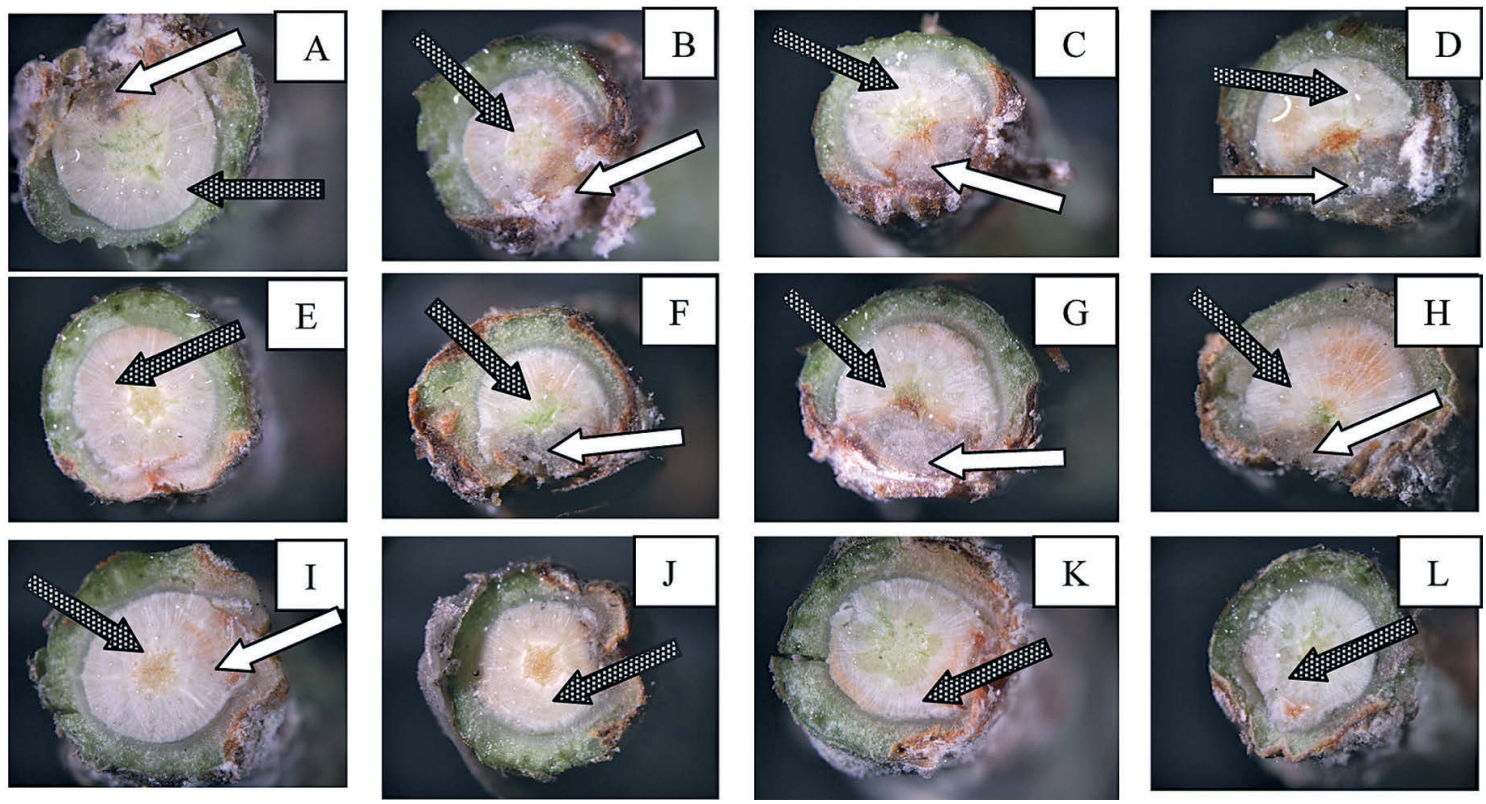

Fig. 2. Cross section through a pine stem at the points of inoculation: A - Grosmannia radiaticola, B - Leptographium lundbergii, C - Leptographium procerum, D - Leptographium truncatum, E - Ophiostoma cf. abietinum, F - Ophiostoma floccosum, G - Ophiostoma minus, H - Ophiostoma piceae, I - Ophiostoma piliferum, $\mathrm{J}$ - Ophiostoma quercus, $\mathrm{K}$ - Sporothrix inflata, $\mathrm{L}$ - control. The white arrow indicates dead parenchyma and sapwood blue stain, while the dark arrow indicates healthy sapwood (photo by R. Jankowiak). 
Table 2

Effects of inoculation of 2-year-old Scots pine seedlings with ophiostomatoid fungi associated with pine-infesting weevils

\begin{tabular}{|c|c|c|c|c|}
\hline Species & $\begin{array}{c}\text { Mean depth of } \\
\text { sapwood blue-stain (mm) }\end{array}$ & $\begin{array}{l}\text { Mean lesion length } \\
(\mathrm{mm})^{*}\end{array}$ & $\%$ dead plants ${ }^{*}$ & Re-isolation (\%) \\
\hline Grosmannia radiaticola & $0.68^{\mathrm{CD}}$ & $8.56^{\mathrm{C}}$ & $13^{\mathrm{ABC}}$ & 100 \\
\hline Leptographium lundbergii & $0.88^{\mathrm{CD}}$ & $11.78^{\mathrm{B}}$ & $23^{\mathrm{AB}}$ & 67 \\
\hline Leptographium procerum & $1.01^{\mathrm{BC}}$ & $8.72^{\mathrm{C}}$ & $17^{\mathrm{ABC}}$ & 100 \\
\hline Leptographium truncatum & $1.29^{\mathrm{AB}}$ & $15.01^{\mathrm{A}}$ & $33^{\mathrm{A}}$ & 60 \\
\hline Ophiostoma cf. abietinum & $0^{\mathrm{F}}$ & $0^{\mathrm{E}}$ & $0^{\mathrm{C}}$ & 86 \\
\hline Ophiostoma floccosum & $0.18^{\mathrm{EF}}$ & $8.50^{\mathrm{C}}$ & $10^{\mathrm{ABC}}$ & 100 \\
\hline Ophiostoma minus & $1.64^{\mathrm{A}}$ & $15.87^{\mathrm{A}}$ & $10^{\mathrm{ABC}}$ & 100 \\
\hline Ophiostoma piceae & $0.24^{\mathrm{EF}}$ & $5.47^{\mathrm{D}}$ & $0^{\mathrm{C}}$ & 100 \\
\hline Ophiostoma piliferum & $0.47^{\mathrm{DE}}$ & $8.30^{\mathrm{C}}$ & $3^{\mathrm{BC}}$ & 53 \\
\hline Ophiostoma quercus & $0^{\mathrm{F}}$ & $0^{\mathrm{E}}$ & $0^{\mathrm{C}}$ & 100 \\
\hline Sporothrix inflata & $0^{\mathrm{F}}$ & $0^{\mathrm{E}}$ & $0^{\mathrm{C}}$ & 80 \\
\hline Control & $0^{\mathrm{F}}$ & $0^{\mathrm{E}}$ & $0^{\mathrm{C}}$ & \\
\hline
\end{tabular}

${ }^{*}$ Depth of sapwood blue-stain, lesion length and seedling mortality with the same letter were not significantly different.

\section{DISCUSSION}

All ophiostomatoid species examined, except Ophiostoma cf. abietinum, Ophiostoma quercus and Sporothrix inflata, were capable of successful infection and symptom development in Scots pine seedlings. Lesions surrounding the point of inoculation in seedlings were observed and they extended beyond the wound beneath the surface of the epidermis. Similar lesion morphology and occurrence have been observed in previous pine seedling inoculation studies with many of the ophiostomatoid species ( $\mathrm{Nevill}$ et al. 1995; Krokene and Solheim, 1998; Ec$\mathrm{khardt}$ et al. 2004; Jankowiak, 2006; M a tusick and Eckhardt, 2010) or without the introduction of fungi (Wing field, 1986; K le p zig et al. 1995; Eck hard t et al. 2004). These studies are the first to confirm lesion development and sapwood penetration associated with artificial inoculation with Grosmannia radiaticola, Leptographium truncatum, Ophiostoma floccosum, O. cf. abietinum, O. quercus, and S. inflata.

The eleven ophiostomatoid species tested in this study differed in their virulence to Scots pine. The seedling mortality as well as necrosis length and depth of sapwood blue-stain indicate that $L$ truncatum and Ophiostoma minus were the most virulent species in this study. The high virulence of $O$. minus is in accordance with the results of other investigations ( $\mathrm{Li} \mathrm{i} \mathrm{e}$ tier et al. 1989; Solheim and Lång ström, 1991; S ol hei m et al. 1993; S ol hei m et al. 2001; J ankowiak et al. 2007). However, previous studies have shown higher virulence of $O$. minus to Scots pine seedlings ( $\mathrm{J}$ a n k ow i a k, 2006; J a n k ow i a k,
2011; Jankowiak, 2012) when compared to the present study. This variation might be caused by differences in the virulence among isolates. Such variation has been reported for isolates of Leptographium wingfieldii, which showed high individual variability in growth characteristics and virulence to Scots pine (L i e u ti e r et al. 2004). Of the eleven species tested, $O$. minus showed the largest radial spreading suggesting its high virulence to Scots pine. Radial movement is most characteristic of highly virulent ophiostomatoid fungi such as Leptographium wageneri (W.B. Kendr.) M.J. Wingf. (C o b b , 1988). These results indicate that this fungus may contribute to the acceleration of tree dieback after attack of Pissodes pini and Pissodes piniphilus in Poland. The data of $\mathrm{J} \mathrm{a} \mathrm{n} \mathrm{k} \mathrm{ow} \mathrm{i} \mathrm{a}$ and B i la ń ski (2013b) could support this statement because these weevils transmitted $O$. minus with high frequency. According to the pathogenicity tests ( $\mathrm{S}$ o 1 heim and Långström, 1991; Solheim et al. 1993; Solheim et al. 2001; Jankowiak et al. 2007), O. minus at high inoculation densities demonstrated high virulence.

The virulence of $L$. truncatum to pine seedlings was surprisingly high, although several species of Leptographium spp. are known to be a primary pathogen of conifers (J a c obs and W ing fi e ld, 2001). This fungus was capable of killing a large part of seedlings and similarly to $O$. minus penetrated deeper into the sapwood than other species. This is in agreement with the studies of J a n k ow i a k (2012) that showed that a genetically similar species $-L$. cf. truncatum isolated from Ips sexdenatus (Börn.) - was pathogenic to Scots pine. Despite the relatively high pathogenicity of L. truncatum to Pinus sylvestris seedlings, its role in 
the dieback of trees after attack of weevils seems to be less important, because this fungus is relatively rarely isolated from weevils ( $\mathrm{Jankowiak}$ and $\mathrm{Bi}$ 1 a ń s k i, 2013ab). However, this fungus may play an important role in increasing seedling mortality during maturation feeding of Hylastes ater (Paykull). Adults of $H$. ater feed on the stem of young pine seedlings, often leading to their death in Poland ( $\mathrm{M} \mathrm{i} \mathrm{ch} \mathrm{als} \mathrm{ki}$ and $\mathrm{Mazur}$, 1999). Leptographium truncatum was recently recorded from Poland mainly in association with this beetle species (J a n k ow i a k and B ilan ski, 2013c). Re a y et al. (2002, 2005) observed a strong relationship between the severity of feeding damage by $H$. ater and the presence and number of Ophiostoma species that colonised the seedlings. To fully explain the level of virulence of $L$. truncatum, further pathogenicity studies of the same fungal isolates should be conducted using roots of older Scots pine trees, although the studies by Krokene and Solhe im (1998) give clear evidence that inoculation of seedlings is a suitable method for determining the virulence of bark beetle-associated blue-stain fungi. However, results from seedling inoculations must be carefully interpreted because young seedlings do not have a well-developed defence system found in older trees (S a ndne s and S ol hei m, 2002).

Consistent with previous results $(\mathrm{Zhou}$ et al. 2002), Leptographium lundbergii also had pathogenic capability because it generated relatively long lesions and caused the death of Scots pine seedlings. However, L. lundbergii gave rise to significantly shorter lesions and to shallower sapwood blue-stain than those associated with $L$. truncatum and $O$. minus, suggesting that this species is not highly pathogenic to Scots pine. The results of this study also indicate that Leptographium procerum has similar pathogenicity characteristics. The low virulence of $L$. procerum in this study is in accordance with previous observations using the same host tree in Poland ( $\mathrm{J}$ a n k owi ak, 2006; J a n k ow i a k et al. 2007) and various Pinus species (W i n g field, 1986; Harrington and Cobb, 1988). It seems that this fungus is highly virulent on Pinus strobus L. (A l e x a n d e r et al. 1988). Due to the close relationship between $L$. procerum and regeneration weevils (J ankowiak and Bilański, 2013ab), the lack of high virulence of this fungus is very important information. This fungus is the predominant fungal organism in many seedlings damaged by maturation feeding of Hylobius abietis adults ( $\mathrm{J}$ a $\mathrm{n} \mathrm{k} \mathrm{o} \mathrm{w} \mathrm{i} \mathrm{a} \mathrm{k} \mathrm{and}$ B ilański , 2013a) and in the galleries of Pissodes castaneus (J a n k ow iak and Bilański, 2013b). The low virulence of $L$. procerum obtained in this study indicated that this fungus rather do not accelerate the dieback of trees attacked by $P$. castaneus on reforestation sites in Poland. The mortality of seedlings destroyed by $H$. abietis also appeared to be a result of severe feeding damage by the beetles, rather than the presence of $L$. procerum in seedlings.

Inoculations with $G$. radiaticola, Ophiostoma piliferum, Ophiostoma piceae, and O. floccosum resulted in very small lesions. These fungi were also not able to penetrate deeply into the sapwood of the seedlings. This new inoculation trial supports previous findings that $O$. piliferum and $O$. piceae are mild pathogens to $P$. sylvestris (Harrington and $\mathrm{Cobb}$, 1983; Jankowiak, 2006; Jankowiak et al. 2007). The present study is also the first to confirm lesion development associated with artificial inoculation with $G$. radiaticola and $O$. floccosum. The former species was the most dominant fungal taxa in the community of ophiostomatoid fungi recorded in association with root-feeding bark beetles ( $\mathrm{Jankowiak}$ and Bilański , 2013c) and was also found in association with H. abietis (J a n k owi a k and B ilańs ki, 2013a) in Poland. In turn, O. floccosum is found occasionally on various bark beetles and weevils infesting pine (J a n k ow i ak and B i la ń ski, 2013ab; Li nnak oski et al. 2012). The present study indicated that these two species should be considered as very weak pathogens of Scots pine.

This study showed that isolates of Ophiostoma cf. abietinum, O. quercus and S. inflata appeared to be non-pathogenic to Scots pine. These fungi are frequently associated with pine-infesting weevils in Poland ( $\mathrm{J}$ a $\mathrm{n}$ k ow i a k and B i lań s ki, 2013ab). In addition, recently $S$. inflata was also found as a frequent root colonizer of dying and dead young $P$. sylvestris trees (J a n k ow i a k et al. 2012). This inoculation test confirmed the supposition of J a n k ow i a k et al. (2012) that $S$. inflata is a saprobe and probably does not play an important role in destroying roots of Scots pine trees. O. cf. abietinum and $O$. quercus probably show the same saprotrophic behaviour in relation to Scots pine.

\section{CONCLUSIONS}

1. Inoculation of Scots pine seedlings demonstrated that pine-infesting weevils were associated with ophiostomatoid fungi differing in virulence to Scots pine seedlings.

2. This study showed that Ophiostoma minus and Leptographium truncatum were more pathogenic than other pine weevil-associated fungi. Of these species, $O$. minus was more consistently associated with Pissodes pini and Pissodes piniphilus than L. truncatum, and it presumably plays a more important role in accelerating the dieback of Scots pine after attack of weevils.

3. The other ophiostomatoid species were non-pathogenic (Ophiostoma cf. abietinum, Ophiostoma 
quercus, and Sporothrix inflata) or weakly pathogenic (Grosmannia radiaticola, Leptographium lundbergii, Leptographium procerum, Ophiostoma floccosum, Ophiostoma piceae, and Ophiostoma piliferum) to Scots pine. The low virulence of $L$. procerum may suggest that the abundant presence of this fungus in seedlings damaged by Hylobius abietis feeding rather does not increase the mortality of seedlings.

\section{Acknowledgments}

The work was supported by grants from the Polish Ministry of Education and Science N N309 049037.

\section{REFERENCES}

Alexander S.A., Horner W.E., Lewis K.J. 1988. Leptographium procerum as a pathogen of pines. [In:] Leptographium root diseases on conifers. T. C. Harrington, F. W. Cobb (eds). St. Paul, Minnesota, APS Press: 97-112.

Cobb F.W. 1988. Leptographium wageneri, cause of black-stain root disease: a review of its discovery, occurrence and biology with emphasis on Pinyon and Ponderosa pine. [In:] Leptographium root diseases on conifers. T. C. Harrington, F. W. Cobb (eds). St. Paul, Minnesota, APS Press: 41-62.

Day K.R., Nordlander G., Kenis M., Halldórs on G. 2004. General biology and life cycles of bark weevils. [In:] Bark and wood boring insects in living trees in Europe, a synthesis. F. Lieutier, K. R. Day, A. Battisti, J. C. Gregoire, H. F. Evans (eds). Kluwer, Dordrecht: 331-349.

Eckhardt L.G., Weber A.M., Menard R.D., Jones J.P., Hess N.J. 2007. Insect-fungal complex associated with loblolly pine decline in central Alabama. For. Sci. 53 (1): 84-92.

Eckhardt L.G., Jones J.P., Klepzig K.D. 2004. Pathogenicity of Leptographium species associated with Loblolly pine decline. Plant Dis. 88: 1174-1178. http://dx.doi.org/10.1094/PDIS.2004.88.11.1174

Harrington T.C., Cobb F.W. 1988. Pathogenicity of Leptographium and Verticicladiella spp. isolated from roots of Western North American conifers. Phytopathology, 73: 596-599.

Jacobs K., Wing field M. J. 2001. Leptographium species: Tree pathogens, insect associates and agents of blue-stain. St. Paul, Minnesota, APS Press.

Jankowiak R. 2006. Fungi associated with Tomicus piniperda in Poland and assessment of their virulence using Scots pine seedlings. Ann. For. Sci. 63:801-808. http://dx.doi.org/10.1051/forest:2006063

Jankowiak R., Rossa R., Bilański P. 2007.Contribution to pathogenicity of three blue-stain fungi associated with the pine sawyer beetle Monochamus galloprovincialis (Coleoptera: Cerambycidae) to Scots pine in Poland. Phytopathologica Pol. 46:37-46.

Jankowiak R. 2011. Assessing the virulence of four blue-stain fungi associated with Tomicus minor using Scots pine seedlings. Phytopathologia, 61: 9-15.

Ja n k owiak R. 2012. Ophiostomatoid fungi associated with Ips sexdentatus on Pinus sylvestris in Poland. Dendrobiology, 68:43-54.

Jankowiak R., Bilański P., Kolařík M., Wasiut a D. 2012. Root-colonizing ophiostomatoid fungi associated with dying and dead young Scots pine in Poland. Forest Pathol. 42 (6): 492-500. http://dx.doi.org/ 10.1111/j.1439-0329.2012.00783

Jankowiak R., Bilański P. 2013a. Diversity of ophiostomatoid fungi associated with the large pine weevil, Hylobius abietis and infested Scots pine seedlings in Poland Ann. Forest Sci. 70: 391-402. http://dx.doi. org/10.1007/s13595-013-0266-z.

Jankowiak R., Bilański P. 2013b. Association of the pine-infesting Pissodes species with ophiostomatoid fungi in Poland. Eur. J. Forest Res. 132: 523-534. http://dx.doi.org/10.1007/s10342-013-0693-2

Jankowiak R., Bilański P. 2013c. Ophiostomatoid fungi associated with root-feeding bark beetles on Scots pine in Poland. Forest Pathol. http://dx.doi.org/10.1111/ efp. 12049

K i r is it s T. 2004. Fungal associates of European bark beetles with special emphasis on the ophiostomatoid fungi. [In:] Bark and wood boring insects in living trees in Europe, a synthesis. F. Lieutier, K. R. Day, A. Battisti, J. C. Gregoire, H. F. Evans (eds). Kluwer, Dordrecht: 185-235.

Klepzig K.D., Kruger E.L., Smalley E.B., R affa K.F. 1995. Effects of biotic and abiotic stress on induced accumulation of terpenes and phenolics in red pines inoculated with bark beetle-vectored fungus. J. Chem. Ecol. 21: 601-626. http://dx.doi.org/10.1007/ BF02033704

Kolk A., Starzyk R.J. 1996. Atlas szkodliwych owadów leśnych. Wydawnictwo Multico, Warszawa. (in Polish)

Krokene P., Solheim H. 1998. Assessing the virulence of four bark beetle-associated blustain fungi using Norway spruce seedlings. Plant Pathol. 47: 537-540. http:// dx.doi.org/10.1046/j.1365-3059.1998.00268.x

Långström B., Solheim H., Hellqvist C., Gref R. 1993. Effects of pruning young Scots pines on host vigour and susceptibility to Leptographium wingfieldii and Ophiostoma minus, two blue-stain fungi associated with Tomicus piniperda. Eur. J. Forest Pathol. 23: 400-415. http://dx.doi.org/10.1111/j.1439-0329.1993.tb00820.x

Lévieux J., Piou D., Cassier P., André M., Guillaumin D. 1994. Association of phytopathogenic fungi for the Scots pine (Pinus sylvestrsis L.) with the European pine weevil Hylobius abietis (L.) (Col. Curculionidae). Canad. Entomol. 126: 929-936. http://dx.doi.org/10.4039/Ent/126929-4

Lieutier F., Yart A., Garcia J., Ham M.C., Morelet M., Levieux J. 1989: Champignons 
phytopathogčnes associés à deux coléoptčres scolytidae du pin sylvestre (Pinus sylvestris L.) et étude préliminaire de leur agressivité envers l'hôte. Ann. Sci. Forest 46: 201-216. (in French)

Lieutier F., Yart A., Ye H., Sauvard D., Gallo is V. 2004. Variations in growth and virulence of Leptographium wingfieldii Morelet, a fungus associated with the bark beetle Tomicus piniperda L. Ann. Forest Sci. 61: 45-53. http://dx.doi.org/10.1051/forest:2003083

Linnakoski R., de Beer Z.W., Niemelä P., Wing field M.J. 2012. Associations of conifer-infesting bark beetles and fungi in Fennoscandia. Insects, 3:200-227. http://dx.doi.org/10.3390/insects3010200

Mathiesen-Käärik A. 1953. Eine Übersicht über die gewöhnlichsten mit Borkenkäfern assoziierten Bläuepilze in Schweden und einige für Schweden neue Bläuepilze. Meddnelanden frín Statens Skogforskningsinstitut 43:1-74. (in German)

Mathiesen-Käärik A. 1960. Studies on the ecology, taxonomy and physiology of Swedish insect-associated blue-stain fungi, especially the genus Ceratocystis. Oikos, 11:1-25. http://dx.doi.org/10.2307/3564881

Matusick G., Eckhardt L.G. 2010. Variation in virulence among four root-inhibiting ophiostomatoid fungi on Pinus teada L., P. palustris Mill, and P. eliottii Engelm. seedlings. Canad. J. Pl. Pathol. 32(3): 361-367. http://dx.doi.org/10.1080/07060661.2010.499268

Michalski J., Mazur A. 1999. Korniki. Praktyczny przewodnik dla leśników. Oficyna Edytorska „Wydawnictwo Świat", Warszawa. (in Polish)

Nevill R.J., Alexander S.A. 1992. Root- and stem-colonizing insects recovered from eastern white pines with procerum root disease. Canad. J. Forest Res. 22: 1712-2726. http://dx.doi.org/10.1139/x92-225

Nevill R.J., Kelley W.D., and Hess N.J. 1995. Pathogenicity to loblolly pines of fungi recovered from trees attacked by southern pine beetles. S. J. Appl. Forest, 19: 78-83.

Piou D. 1993. Rôle d'Hylobius abietis (L.) (Col, Curculionidae) dans le transport de Leptographium procerum (Kendr.) Wingf. Et son inoculation au Pin sylvestre. Ann. Sci. Forest, 50:297-308.

Reay S.D., Thwaites J.M., Farrell R.L. 2005. A survey of Ophiostoma species vectored by Hylastes ater to pine seedlings in New Zealand. Forest Pathol. 35: 105-113. http://dx.doi.org/10.1111/j.1439-0329.20 04.00393.x

Reay S.D., Walsh P.J., Ram A., Farrell R.L. 2002. The invasion of Pinus radiata seedlings by sapstain fungi, following attack by the Black Pine Bark Beetle, Hylastes ater (Coleoptera: Scolytidae). Forest Ecol. Managem. 165: 47-56.

Sandnes A., Solheim H. 2002. Variation in tree size and resistance to Ceratocystis polonica in a monoclonal stand of Picea abies. Scand. J. Forest Res. 17: 522-528. http://dx.doi.org/10.1080/02827580260417170

Solheim H., Krokene P., Língström B. 2001. Effects of growth and virulence of associated blue-stain fungi on the host colonisation behaviour of pine shoot beetles Tomicus minor and T. piniperda. Plant Pathol. 50: 111-116. http://dx.doi.org/10.1046/j.1365-3059.20 01.00541.x

Solheim H., Língström B. 1991. Blue-stain fungi associated with Tomicus piniperda in Sweden and preliminary observations on their pathogenicity. Ann. Sci. Forest 48: 149-156.

Solheim H., Língström B., Hellqvist C. 1993. Pathogenicity of the blue-stain fungi Leptographium wingfieldii and Ophiostoma minus to Scots pine: effect of tree pruning and inoculum density. Canad. J. Forest Res. 23: 1438-1443. http://dx.doi.org/10.1139/x93-181

Wallertz K., Örlander G., Luoranen J.2005. Damage by pine weevil Hylobius abietis to conifer seedlings after shelterwood removal. Scand. J. Forest Res. 20: 412420. http://dx.doi.org/10.1080/028275805003069954

Wing field M. J. 1983. Association of Verticicladiella procera and Leptographium terebrantis with insects in the Lake States. Canad. J. Forest Res. 13: 1238-1245. http://dx.doi.org/10.1139/83-162

Wingfield M.J. 1986. Pathogenicity of Leptographium procerum and L. terebrantis on Pinus strobus seedlings and established trees. Eur. J. Forest Pathol. 16: 299-308. http://dx.doi.org/10.1111/j.1439-0329.1986.tb00195.x

Zanzot J.W., Matusick G., Eckhardt L.G. 2010. Ecology of root-feeding beetles and their associated fungi on Longleaf Pine in Georgia. Environ. Entomol. 39(2): 415-423. http://dx.doi.org/10.1603/EN09261

Zhou Xu., DeBeer W., Wingfield B.D., Wingfield M.J. 2002. Infection sequence and pathogenicity of Ophiostoma ips, Leptographium serpens and Leptographium lundbergii to pines in South Africa. Fungal Divers. 10: 229-240.

\section{Ocena wirulencji grzybów ofiostomatoidalnych związanych z ryjkowcami w stosunku do sadzonek sosny zwyczajnej (Pinus sylvestris L.)}

\section{Streszczenie}

Dwuletnie sosny rosnące w kontenerach z podłożem torfowo-perlitowym były inokulowane dwutygodniową grzybnią wyrosłą na 2-procentowej pożywce agarowo-maltozowej. Kontrolę stanowiło 30 sadzonek inokulowanych sterylną pożywką. Badano 11 gatunków grzybów związanych z owadami z rodziny ryjkowcowatych (Curculionidae) żerującymi na sośnie zwyczajnej. Leptographium truncatum (M.J. Wingf. \& Marasas) M.J. Wingf., L. lundbergii Lagerb. \& Melin, L. procerum (W.B. Kendr.) M.J. Wingf., Grosmannia radiaticola (J.J. Kim, Seifert \& G.H. Kim) Zipfel, Z.W. de Beer \& M.J. Wingf., Ophiostoma cf. abietinum Marm. \& Butin, O. floccosum Math.-Käärik, minus (Hedgc.) Syd. \& P. Syd., O. piliferum 
(Fr.) Syd. \& P. Syd., piceae Münch) Syd.\& P. Syd., O. quercus (Georgev.) Nannf. i Sporothrix inflata de Hoog. Sadzonki zakażano poprzez nacięcie strzałki pędu i wprowadzenie inokulum w postaci krążka pożywki z grzybnią.

Izolaty $L$. truncatum i $L$. lundbergii spowodowały zamarcie $23-33 \%$ roślin, zaś izolaty $L$. procerum, G. radiaticola, O. floccosum i $O$. minus przyczyniły się do śmierci 10-17\% sadzonek sosny. Ophiostoma piliferum spowodował zamarcie jednej sadzonki. U żadnej sadzonki kontrolnej ani sadzonki zakażanej grzybami $O$. cf. abietinum, O. piceae, $O$. quercus i $S$. inflata nie zaobserwowano objawów chorobowych. Wszystkie gatunki grzybów, z wyjątkiem $O$. cf. abietinum, $O$. quercus i $S$. inflata spowodowały na strzałce pędu powstanie ciemnobrunatnych nekroz. Ophiostoma minus i L. truncatum indukowały wyraźnie dłuższe nekrozy niż inne grzyby i niż te występujące na sadzonkach kontrolnych. Wszystkie gatunki grzybów, z wyjątkiem $O$. cf. abietinum, $O$. quercus i $S$. inflata, spowodowały siniznę drewna bielastego u inokulowanych sadzonek. Podobnie jak w przypadku nekroz, także $O$. minus i $L$. truncatum spowodowały najgłębsze przebarwienie drewna bielastego sadzonek sosny. 
